\title{
DINAMIKA GEJALA KEJENUHAN BELAJAR SISWA PADA PROSES BELAJAR ONLINE FAKTOR FAKTOR YANG MELATARBELAKANGI DAN IMPLIKASINYA PADA LAYANAN BIMBINGAN KELUARGA (Penelitian terhahap siswa kelas VIII MTs Negeri 3 Bandung Tahun Pelajaran 2020/2021)
}

\author{
DEDEH KURNIA \\ MTs Negeri 3 Bandung \\ Email : dedehkurniamtsn3bandung@gmail.com
}

\begin{abstract}
ABSTRAK
Proses belajar mengajar yang dilakukan pada masa pandemic covid 19 sangat berbeda dengan proses belajar pada umumnya. Proses belajar yang dilakukan di rumah secara daring/online tidak menghadirkan sosok guru secara nyata sehingga dimungkinkan siswa hanya sekedar menerima infomasi pelajaran semata. Kegiatan menerima informasi pelajaran semata seringkali menimbulkan kejenuhan bagi siswa karena pembelajan cenderung satu arah saja, sehingga diperlukan bimbingan dari orang tua dan atau keluarga untuk dapat mengetahui lebih dalam gejala kejenuhan tersebut beserta faktor yang melatarbekanginya sehingga orang tua/ keluarga mampu mencari formula yang tepat sebagai sarana pendampingan terhadap siswa yang sedang melakukan proses belajae online/daring dari rumah dengan memberikan layanan bimbingan akademik terhadap siswa. Sehingga meskipun siswa belajar dari rumah para siswa tetap dapat merawat semangat belajar dengan baik dan dapat menghadirkan suasana belajar yang kondusif di rumah sehingga proses pembelajaran dapat terlaksana secara optimal. Pendekatan yang digunakan dalam penelitian adalah kuantitatif dengan metode survey. Data penelitian diperoleh secara online melalui google form. Sampel penelitian adalah siswa kelas VIII MTs Negeri 3 Bandung Tahun Pelajaran 2020/2021 yang berjumlah 307 orang terdiri dari 150 siswa laki-laki dan 157 siswa perempuan. Hasil dari penelitiian menunjukkan bahwa kejenuhan belajar, faktor yang melatarbelakangi berada pada empat indikator yaitu :semangat belajar, emosi belajar dan menurunnya keyakinan akademik dengan prosentae yang amat tinggi pada kategori ya dan tidak. Tentu perlu solusi untuk mengatasi kejenuhan belajar ini supaya proses belajar online tetap dapat dilakukan dengan baik dan optimal.
\end{abstract}

Kata kunci : kejenuhan. Belajar. Layanan bimbingan akademi

\section{PENDAHULUAN}

Pademi Covid 19 yang mewabah hampir diseluruh belahan dunia telah mengubah segala sisi kehidupan manusia, Anjuran jaga jarak, tidak berkerumun dan lebih baik berada dirumah (Stay at Home),yang dimaksudkan untuk memutus mata rantai penyebaran virus covid 19 membuat aktivitas manusia dibatasi dan dirubah sesuai ketentuan, pembatasan dan perubahan dapat dirasakan dengan diberlakukannya WFH (Work From Home) bagi mereka yang bekerja di kantor dan BDR (belajar dari 
rumah), belajar jarak jauh atau lebih dikenal dengan istilah belajar secara daring (dalam jaringan)/online, sesuai dengan intruksi Menteri Pendidikan Republik Indonesia. (Kementerian Pendidikan dan Kebudayaan Republik Indonesia,2020).

Proses belajar mengajar daring/online atau jarak jauh tentu saja berbeda dengan belajar tatap muka, perbedaan yang paling esensi adalah adanya interaksi yang terbatas antara guru dan siswa dalam proses belajar mengajar, interaksi hanya dapat dilakukan melalui media belajar seperti Google Form, Google Class, atau bahkan hanya melalui Whats Up saja. Dengan demikian guru hanya bertindak sebagai mediator dan fasilitator yang menyampaikan materi materi pelajaran tanpa melihat langsung sisi psikologis siswa dalam proses belajar. Perbedaan selanjutnya adalah para guru tidakldapat membentuk secara langsung suasana belajar yang nyaman agar para siswa dapat mengkuti proses pembelajarn dengan baik. Padahal pembentukkan suasana belajar merupakan hal yang penting dilakukan dalam proses belajar mengajar, sesuai dengan Undang Undang Sistem Pendidikan Nasional. No. 20 Tahun 2003, Pendidikan adalah usaha sadar dan terencana untuk mewujudkan suasana belajar dan proses pembelajaran agar peserta didik secara aktif mengembangkan potensi dirinya untuk memiliki kekuatan spiritual keagamaan, pengendalian diri, kepribadian, kecerdasan, akhlak mulia, serta keterampilan yang diperlukan dirinya dan masyarakat. Dari paparan undang undang sistem Pendidikan No 20 Tahun 2003, jelas bahwa pembentukan suasana dalam proses belajar merupakan hal yang penting dilakukan karena akan sangat berpengaruh pada keberhasilan tujuan pembelajaran dan pendidikan. Dengan demikian pembentukkan Susana belajar harus tetap dilakukan agar tujuan pembelajaran tercapai dengan baik, dan selama proses BDR (belajar dari Rumah atau belajar secara on line pembentukkan suasana belajar menjadi tanggung jawab orang tua sebagai pengganti guru di sekolah.

Wilis (2013) mengungkapkan bahwa sistem sekolah dan keluarga sangat mempengaruhi perilaku anak dan remaja. Peran utama dipegang guru dan orang tua. Orang tua dituntut untuk mampu menghadirkan suasana yang nyaman untuk belajar di rumah sehingga tidak mengurangi esensi belajar dan tujuan dari proses pembelajaran. Diantara proses pembentukkan suasana belajar nyaman di rumah adalah dengan mengubah lingkungan rumah menjadi seperti lingkungan sekolah dalam arti menyediakan sedikit ruang dan waktu khusus untuk belajar serta peran orang tua berubah menjadi seorang guru. Sebagaimana di ungkapkan oleh Yusuf (2010: 39), bahwa keluarga memiliki fungsi Edukatif (Pendidikan)yakni keluarga merupakan lingkungan pendidikan pertama dan utama bagi anak. Keluarga berfungsi sebagai "transmitter budaya atau mediator " bagi anak. Hal senada juga diulas dalam sebuah pribahasa arab yang menyebutkan bahwa " Al Um Madrosatul Aulad, artinya seorang ibu sekolah pertama bagi anak anaknya. Selanjutnya Yusuf (2010) mengatakan bahwa fungsi keluarga dalam pendidikan adalah berkaitan dengan penanaman, pembimbingan atau pembiasaan nilai-nilai agama budaya dan keterampilan- keterampilan yang sangat bermanfaat bagi anak.

Islam telah lama hadir dan menganjurkan orang tua untuk dapat berperan serta dalam proses pendidikan sebagaimana yang diungkapkan dalam sebuah hadits dalam 
(Zakaria : 2010), bahwa setiap anak dilahirkan dalam keadaan fitrah (tauhidullah), maka pengaruh pendidikan orang tuanya lah dia menjadi majusi atau nasrani (HR Bukhori Muslim). Dari hadits tersebut jelas bahwa Rosul memberikan informasi penting bahwa keluarga memiliki peran penting dalam proses pendidikan. Keluarga tidak hanya memiliki tugas untuk membesarkan anak secara fisik akan tetapi harus membekali anak secara moral dan akhlak mulia.

Sayangnya tidak semua orang tua mampu menghadirkan suasana belajar di rumah dan tidak mampu berperan sebagai seorang guru di rumah, utamanya dalam keadaan sulit terlilit pandemic covid 19 seperti sekarang ini, fakta dilapangan banyak orang tua mengeluhkan betapa kesulitan mengajari anak, meminta anak belajar dan mengerjakan tugas. Kompas TV, hari selasa tanggal 15 September 2020, merilis sebuah kejadian pilu terjadi di Bogor, seorang ibu melukai anaknya yang tidak mau belajar dari rumah, bahkan di banten seorang anak meregang nyawa dipukul oleh orang tuanya karena tidak mau belajar di rumah. Orang tua cenderung otoritas dan mengedepankan emosi dalam membimbing anak untuk belajar di rumah, bahkan sebagian besar orang tua tidak memerhatikan anak belajar karena berbagai alasan, seperti orang tua tidak faham, orang tua tidak mengerti serta orang tua tidak berada di rumah karena harus bekerja , dan ada juga yang siswa tidak tinggal bersama orang tua.

Ketidakpedulian dan ketidakmampuan orang tua dalam proses pengajaran anak di rumah membuat proses pembelajaran di rumah tidak memiliki suaana belajar yang seharusnya. Sehingga anak-anak di rumah merasa kurang terbimbing yang pada akhirnya merasa kurang bersemangat belajar bahkan merasa jenuh dalam proses belajar. Kejenuhan dilatari oleh kurangnya bimbingan baik dari orang tua mauoun orang dewasa lainnya di rumah yang diharapkan mampu menjadi sosok pengganti seorang guru yang nyata berhadapan dengan siswa

Kejenuhan secara harfiah menurut Suhayadi (2020) memiliki arti padat atau penuh sehingga tidak mampu lagi memuat apa pun. Kejenuhan dalam belajar adalah rentang waktu yang digunakan untuk belajar akan tetapi tidak mendatangkan hasil. Menurut Cherniss dalam Ramadhani (2013)menyebutkan kejenuhan belajar adalah suatu keadaan kelelahan fisik, mental, sikap dan emosi indiviu atau pekerjaan karena keterlibatan yang intensif dengan pekerjaan dalam jangka waktu yang panjang. Selanjutnya Cherniss menjelaskan kelelahan fisik akan berdampak pada kemandegan pencapaian prestasi individu baik secara pribadi, akademik, sosial maupun professional.

Penelitian yang dilakukan Ramadhani tahun 2013 menyebutkan bahwa kejenuhan belajar dapat terjadi pada siswa karena pikiran negatif siswa yang menganggap tugas terlalu banyak dan membebankan karena tugas tidak dipersepsi sebagai kebaikan bagi prestasi akademis. Agustin (2009) memberikan penjelasan bahwa kejenuhan elajar merupakan suatu keadaan yang menunjukkan kelelahan yang dialami peserta didik baik secara fisik maupun mental, sikap dan emosi dalam rentang waktu tertentukarena keterlibatan yang intensif dengan tugas yang tidak menghasilkan prestasi yang semakin baik.

Ramadhani (2013) dalam penelitiannya menyebutkan bahwa salah satu faktor terjadinya kejenuhan belajar pada siswa adalah tidak adanya dukungan sosial 
terhadap siswa, kejenuhan muncul disebabkan tidak adanya hubungan baik siswa dengan orang lain dan lingkungannya. Agustin (2009) mengemukakan bahwa keacuhan teman, ketidakpekaan dosen, lembaga dan orang tua yang tidak peduli, kurangnya apresiasi masyarakat terhadap peserta didik, ruang kuliah terlalu padat, tugas akademik yang berlebihan, bangunan fisik sekolah yang tidak baik, hilangnya otonomi dan keuangan yang tidak memadai merupakan beberapa faktor lingkungan sosial yang berperan menimbulkan kejenuhan belajar.

\section{METODE PENELITIAN}

Pendekatan yang digunakan dalam penelitian adalah kuantitatif dengan metode survey, metode survey yakni mendeskripsikan secara kuantitatif kecenderungan perilaku dari suatu populasi dengan meneliti sampel populasi tersebut (Craswell, 2008). DaLam penelitian ini perilaku yang dimaksud adalah terkait dengan kejenuhan yang dialami para siswa kelas VIII MTs Negeri 3 Bandung dalam proses pembelajaran on line pada masa pandemic covid 19. Data penelitian diperoleh secara online dengan menggunakan media google form. Responden dalam penelitian ini adalah siswa kelas VIII MTs Negeri 3 Bandung Tahun Pelajaran 2020/2021 yang tersebar di 10 kelas dengan jumlah 150 orang siswa laki-laki dan 157 orang siswa perempuan.

Instrument yang digunakan dalam proses penelitian dengan menggunakan angket mengenai kejenuhan belajar bagi siswa kelas VIII MTs Negeri 3 Bandung .merupakan instrument yang mengungkap tingkat kejenuhan siswa serta faktor yang melatarbelaknginya. Yang dibagi ke dalam 3 indikator yaitu : (1) Indikator Kelelahan Emosi Belajar (dengan pernyataan nomor 1-19) dan (2) indikator depersonalisasi (dengan pernyataan 20-24) (3) Indikator menurunnya keyakinan akademik (dengan pernyataan nomor 25-30). Jumlah pernyataan yang diajukan dalam angket ini 30 pernyataan dengan alternative jawaban menggunakan skala guttman dengan alternative jawaban ya tidak. Pengolahan data menggunakan system docs.google.com.documen yang secara langsung menghasilkan deskripsi data prosentase berdasarkan pernyataan pernyataan yang dijawab oleh responden.

Adapun alur penelitiannya dijelaskan pada gambar 1 dibawah ini :

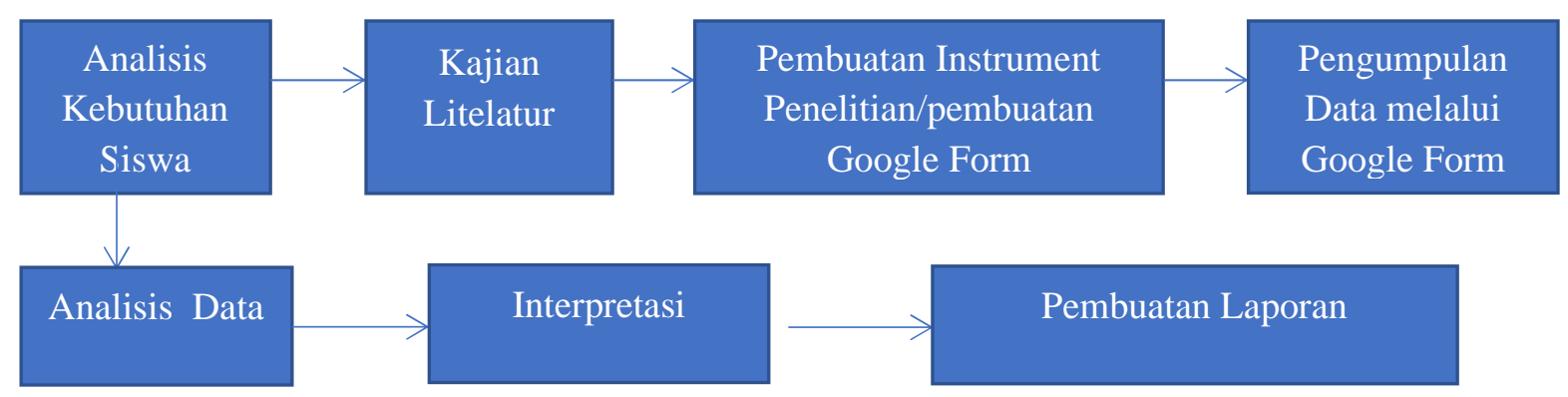

Gambar I. Alur Penelitian 


\section{HASIL DAN PEMBAHASAN}

Hasil penelitian yang akan diuraikan mencakup 3 indikator yaitu : (1) indikator kelelahan emosi belajar (dengan pernyataan nomor 1-19) dan (2) indikator depersonalisasi (dengan pernyataan 20-24) (3) Indikator menurunnya keyakinan akademik (dengan pernyataan nomor 25-30).

Hasil penelitian pada indikator kelelahan emosi belajar menunjukkan hasil sebagaimana tertuang pada table 1 berikut ini :

Tabel 1. Kelelahan Emosi Belajar

\begin{tabular}{|c|c|c|c|}
\hline No & Pernyataan & Ya & Tidak \\
\hline 1. & Saya sering merasa malas mengikuti proses belajar on line & $38,1 \%$ & $61,9 \%$ \\
\hline 2. & Saya sering telat masuk pada kelas online & $39,6 \%$ & $60.4 \%$ \\
\hline 3. & Saya cuek dalam mengikuti pelajaran on line di kelas & $70,9 \%$ & $29,1 \%$ \\
\hline 4. & Saya pasif dalam mengikuti proses belajar on line & $50 \%$ & $50 \%$ \\
\hline 5. & $\begin{array}{l}\text { Saya merasa nilai saya kurang bagus selama proses belajar } \\
\text { online }\end{array}$ & $85,8 \%$ & $14,2 \%$ \\
\hline 6. & saya kurang tertarik dengan proses belajar on line & $68,7 \%$ & $31,3 \%$ \\
\hline 7. & $\begin{array}{l}\text { saya merasa metode sekolah on line kurang cocok dengan } \\
\text { diri saya }\end{array}$ & $68.7 \%$ & $31.3 \%$ \\
\hline 8. & Saya mengimginkan sekolah tatap muka di kelas & $97 \%$ & $3 \%$ \\
\hline 9. & saya menginginkan guru mengajar langsung di kelas & $97 \%$ & $3 \%$ \\
\hline 10 . & Belajar online membuat tugas sekolah sangat banyak & $77,6 \%$ & $22,4 \%$ \\
\hline 11. & $\begin{array}{l}\text { Saya sering keteteran dalam mengerjakan tugas selama } \\
\text { belajar dirumah }\end{array}$ & $76.1 \%$ & $23,9 \%$ \\
\hline 12 & Saya merasa tugas saya dikerjakan asal asala & $55,2 \%$ & $44,3 \%$ \\
\hline 13. & Saya suka buru buru dalam mengerjakan Tugas & $45 \%$ & $55 \%$ \\
\hline 14 & Saya merasa nilai saya menurun selama proses belajar online & 79,1 & 20,9 \\
\hline 15. & Saya kecewa dengan nilai yang diperoleh & 67,2 & 32,8 \\
\hline 16. & $\begin{array}{l}\text { Saya merasa kurang konsentrasi dengan proses belajar on } \\
\text { line }\end{array}$ & 85,1 & 14,9 \\
\hline
\end{tabular}




\begin{tabular}{|l|l|l|l|}
17, & $\begin{array}{l}\text { Saya sering tidak mengerti dengan pelajaran yang } \\
\text { disampaikan pada kelas online }\end{array}$ & 85,8 & 14,2 \\
\hline 18. & $\begin{array}{l}\text { Saya sering pusing dengan pelajaran yang disampaikan pada } \\
\text { kelas online }\end{array}$ & 83,6 & 15.4 \\
\hline 19. & Saya diam ketika tidak mengerti pada pelajaran & 61,9 & 38,1 \\
\hline
\end{tabular}

Hasil penelitian terkait indikator Depersonalisasi menunjukkan hasil sebagaimana tertuang pada Tabel 2 berikut ini.

Tabel 2. Depersionalisasi

\begin{tabular}{|c|l|c|c|}
\hline No & \multicolumn{1}{|c|}{ Pernyataan Depersonalisasi } & Ya & Tidak \\
\hline 1. & $\begin{array}{l}\text { Saya merasa tugas sekolah online lebih banyak dari tugas } \\
\text { sekolah tatap muka }\end{array}$ & $77,6 \%$ & $22,4 \%$ \\
\hline $\mathbf{2 .}$ & Saya sering kelelahan dengan tugas sekolah & $76,1 \%$ & $23,9 \%$ \\
\hline $\mathbf{3 .}$ & Saya sering tidak hadir di kelas online & $31,3 \%$ & $68,7 \%$ \\
\hline $\mathbf{4 .}$ & $\begin{array}{l}\text { Saya sering memilih untuk main game dari pada ikut belajar } \\
\text { online }\end{array}$ & $13,4 \%$ & $86,6 \%$ \\
\hline $\mathbf{5 .}$ & Saya lebih tertarik untuk main bersama teman daripada belajar & $27,6 \%$ & $72,4 \%$ \\
\hline
\end{tabular}

Hasil penelitian terkait indikator Menurunnya keyakinan akademik menunjukkan hasil sebagaimana tertuang pada Tabel 3 berikut ini.

Tabel 3. Menurunnya keyakinan belajar

\begin{tabular}{|c|l|c|c|}
\hline NO & \multicolumn{1}{|c|}{ Pernyataan Menurunnya Keyakinan Akademik } & Ya & Tidak \\
\hline 1. & Saya merasa kurang tertarik belajar online & $72,6 \%$ & $22,4 \%$ \\
\hline 2. & Saya tidak bersemangat untuk mengikuti belajar online & $52,3 \%$ & $47,7 \%$ \\
\hline 3. & Saya mengikuti belajar online karena takut tidak naik kelas & $83,4 \%$ & $16,4 \%$ \\
\hline 4. & Saya ikut belajar online karena takut sama guru & $58,2 \%$ & $41,8 \%$ \\
\hline 5. & Saya mengikuti belajar online hanya isi absen saja & $26,9 \%$ & $73,1 \%$ \\
\hline 6. & Saya belajar on line asal asalan & $29 \%$ & $71 \%$ \\
\hline
\end{tabular}


Pandemi covid 19 telah mengubah dunia, aktivitas manusia tidak dapat dijalankan secara normal hampir pada semua sektor termasuk pada sektor pendidikan yang memaksa seluruh civitas akademika pada semua jenjang harus melakukan proses belajar dengan menggunakan metode online atau dikenal dengan proses belajar daring atau belajar dari rumah (BDR). Proses belajar online tentu saja merupakan metode baru yang sebelumnya belum banyak digunakan sekolah pada umumnya sehingga para siswa merasa kaget dan tidak biasa karena sebelumya proses belajar dilakukan seacara tatap muka di kelas nyata lengkap dengan guru dan suasana sosial yang terbangun pada saat proses beajar berlangsung. Tidak hadirnya sosol guru secara nyata dan proses belajar dilakukan secara online maka memunculkan permasalahan yang dihadapi siswa sehingga siswa merasa jenuh dalam proses belajar. Maka berikut hasil analisis hasil penelitian mengenai kejenuhan belajar dan faktor yang melatarinya pada proses belajar online masa pandemic covid 19.

Berdasarkan hasil penelitian terkait dengan indikator kelelahan emosi belajar Siswa Kelas 8 MTs Negeri 3 Bandung pada belajar online didominasi pada kategori ya, yang menggambarkan siswa memiliki kelelahan atau keletihan emosi yang tinggi pada proses belajar online. Kelelahanemosi merupakan indikator dari kejenuhan yang melanda sseorang, seperti yang dikatakan Maslach \& Leiter (1996) dalam Ramadhani (2013) menyebutkan bahwa individu yang mengalami kejenuhan belajar akan merasa enenrginya habis secara emosi, mudah putus asa dan frustasi. Selanjutnya Noushad dalam Ramadhani 2013 menjelaskan bahwa keletihan emosi akibat kejenuhan belajar ditandai dengan sikap mudah menyerah, mudah lelah dan lesu tanpa gairah belajar. Keletihan emosi ini membuat seseorang merasa tidak semangat belajardan merasa tidak memiliki energy untuk mendapatkan hal yang penting bagi dirinya sendiri.

Selaras dengan pendapat yang diungkapkan Houkes pada laman psikologi on line bahwa keletihan emosi dapat ditimbulkan oleh : 1) Beban kerja (workload), yaitu tekanan yang timbul dari pekerjaan yang dikerjakan seseorang. 2) Tekanan waktu (time pressure), yaitu timbul dari ketegangan yang dihadapi oleh seseorang dalam menyelesaikan pekerjaannya, dimana ketegangan itu dapat timbul dari sebuah tuntutan penyelesaian pekerjaan (deadline). 3) Kurangnya dukungan sosial (lack of social support) yaitu keadaan dimana terjadi kekurangan terhadap dukungan dari orang-orang di sekitarnya untuk melakukan pekerjaan. 4) Stress karena peran (role stress), diartikan bahwa seseorang mengalami sebuah ambiguitas terhadap pekerjaannya dan tengah menghadapi konflik dalam pekerjaannya.

Dalam proses belajar online siswa merasa bahwa mereka memiliki tugas lebih banyak daripada sekolah tatap muka sehingga beban pekerjaan atau beban belajar yang dirasakan siswa lebih banyak, selain itu siswa merasa tuntutan waktu yang membuatnya harus menyelesaikan tugas tepat pada waktunya dan yang terpenting siswa tidak memiliki dukungan sosial dalam hal ini siswa merasa tidak memiliki pendamping atau guru sebagai sumber informasi belajar selama belajar di rumah karena ketidaksiapan orang tua yang diharapkan mampu menjadi guru di rumah, sehingga siswa yang belajar online di rumah kehilangan sosok guru yang diharapkan dapat membimbing siswa selama belajar di rumah, Kehadiran guru atau pendamping belajar memang sangat penting karena guru selain sebagai fasilitator belajar juga dapat menyuguhkan suasana belajar yang kondusif sehingga siswa merasa nyaman 
dan semangat belajar. Hal ini seperti yang di ungkapkan Agustin dkk (2020) , kegiatan belajar yang menyajikan tatap muka antara guru dan siswa akan membangkitkan semangat belajar pada siswa, mereduksi kecemasan, dan dapat membangkitkan rasa percaya diri pada diri siswa. Yusuf (2020) dalam new.com mengemukakan bahwa kebosanan atau kejenuhan yang dihadapi siswa selain minimnya peran orang tua di rumah juga disebabkan oleh ketidakmampuan siswa dalam mencerna setiap informasi pelajaran dari guru dan tidak ada tempat untuk bertanya sehingga timbul rasa bosan, jenuh dan malas pada diri siswa, dampaknya adalah menurunnya nilai yang diperoleh siswa.

Dengan kata lain, kejenuhan dalam proses belajar siswa di rumah bagi siswa sangat mungkin terjadi hal ini ditunjukkan dengan sikap pasif para siswa dalam menanggapi setiap materi pelajaran yang disampaikan guru, serta sisaw merasa metode yang dibeikan guru kurang cocok dengsn dirinya sebagai siswa.

Terkait dengan depersonalisasi, depersonalisasi diartikan sebagai pasif dalam kegiatan belajar menganggap mudah mata pelajaran, merasa terbebani dengan banyaknya tugas belajar, tidak yakin dengan apa yang sedang dipelajari dan berupaya untuk mengalihkan diri dari kegiatan belajar. Terkait dengan indikator depersonalisasi nampak siswa menunjukkan sikap yang lelah, letih merasa beban dalam menghadapi materi materi pelajaran sehingga siswa seringkali mengalikkan aktivitas belajar on line kepada kegiatan bermain seperti bermain game. Dan tidak heran jika siswa seringkali hanya mengisi absen saja karena siswa merasa malas untuk mengikuti materi pelajaran setelah absen.

Pemberian motivasi dan penguatan terhadap siswa merupakan dua hal yang sangat penting diberikan terhadap siswa yang sedang melakukan proses belajar di rumah . pemberian motivasi dan penguatan dapat dilakukan oleh guru sebagai pengajar yang setiap hari hadir di kelas on line dengan kata lain guru hendaknya memberikan ruang atau sedikit waktu untuk membuka pelajaran dengan obrolan ringan sebagai pembuka pelajaran sehingga siswa tidak hanya menerima materi pelajaran akan tetapi mendapatkan motivasi dan penguatan dari guru. Selain guru, orang tua dapat memberikan motivasi di rumah agar anak tidak bosan dan jenuh pada proses belajar di rumah, Dosen Fakultas FISIP Universitas Nasional Dr. Dwi Kartikawati, mengatakan peran orangtua dalam E-Learning sangat besar karena sebagai pemberi semangat dan motivasi untuk tetap belajar. Tak hanya itu, keberadaan orang tua juga untuk memastikan anak belajar e-learning fokus dan aman, memahami kelebihan serta kekurangan anak. Pemberian motivasi dan penguatan penting dilakukan agar siswa merasa nyaman dan semangat untuk melakukan proses pembelajaran. Motivasi dan penguatan dapat dilakukan dengan memberikan kalimat kalimat semangat atau pun pengkondisian lingkungan belajar yang dilakukan rumah seperti memberikan ruang dan fasilitas belajar yang memadai bagi siswa yang sedang belajar di rumah. Pemberian fasilitas belajar merupakan salah satu kewajiban yang harus diberikan orang tua terhadap siswa.

Guru dalam hal ini dapat melakukan cara mengajar atau menggunakan metodologi menajar dengan membuat inovasi inovasi metode mengajar seperti video pembelajaran dimana guru dapat secara langsung menerangkan materi ajar dengan menggunakan picture picture yang menarik untuk siswa, sehingga siswa dapat 
mengamati materi yang menarik membuat siswa semangat mengikuti proses belajar. Selain itu guru juga dapat memanfaatkan teknologi belajar dengan menggunaka live zoom meeting, ggoggle meet atau webex meet sebagai sarana kelas sehingga dalam proses belajar, seolah olah guru hadir dihadapan siswa dalam memberikan materi pengajaran sehingga interaksi antara guru dan siswa dapat terbangun, dalam arti jika ada materi pelajaran yang kurang difahami siswa dapat br

Hasil penelitian terkait dari indikator menurunnya keyakinan akademik, para siswa kelas VIII MTs Negeri 3 Bandung menunjukkan bahwa keterlibatan para siswa dalam proses belajar on line hanya karena siswa merasa takut tidak naik kelas, takut tidak memiliki nilai dan takut oleh guru. Siswa belajar belum seutuhnya memiliki motivasi yang kuat dari dalam diri sendiri, sejatinya motivasi harus muncul dari dalam diri siswa atau lebih dikenal dengan istilah motivasi instrinsik , baik sedang belajar di sekolah maupun belajar di rumah, karena dengan memiliki motivasi yang tinggi maka akan semangat yang tinggi seperti diungkapkan oleh Abin Syamsudin (2003) dalam memahami motivasi seseorang dapat dilihat dari bebrapa indikator, diantaranya : 1) durasi kegiatan yang dilakukan individu, orang memiiki motivasi terhadap sebuah kegiatan cenderung akan memiliki durasi lebih lama dalam mengerjakan sebuah kegiatan karena kecintaannya pada kegiatan tersebut, 2), frekuensi kegiatan, seseorang yang memiliki motivasi leih banyak dan kuat akan lebih sering melakukan sebuah kegiatan yang disenanginya, 3), keuletan dan kemampuan dalam menghadapi setiap rintangan dan halangan yang dihadapi, 4). Berani berkorban demi untuk mencapai tujuan 5), memikili kualitas produk yang dihasilkan. Bila para siswa memiliki indikator-indikator tersebut maka para siswa akan menunjukkan kualitas belajarnya dan tidak akan melakukan proses belajar hanya karena takut oleh guru semata.

Siswa pada masa sekolah menengah pertama atau dalam hal ini Madrasah Tsanawiyyah merupakan siswa yang berada pada tahap remaja awal, Yusuf : 209 mengungkapkan remaja awal sering diartikan sebagai individu dalam proses berkembang ke arah kematangan atau kemandirian, untuk mencapai kematangan remaja memerlukan bimbingan karena remaja tidak memiliki pemahaman yang cukup baik mengenai dirinya atau pun lingkungannya. Bimbingan dapat dilakukan oleh orang dewasa disekeliling remaja baik itu guru, konselor maupun orang tua agar remaja terbimbing baik aktivitas belajarnya maupun akvitas lainnya. Santrock (2003 : 253) bagi remaja sekolah berfungsi sebagai rancangan untuk melatih remaja secara intelektual dan juga di bidang kesiapan kerja dan sosial. Dengan kata lain sekolah bukannya berfungsi sebagai menajamkan sisi akademik siswa akan tetapi belajar mengenai kesiapan dalam menghadapi kehidupan yang lebih luas. Sehingga pros pembimbingan remaja sebagai siswa baik sedang sekolah tatap muka ataupun sekolah di rumah atau online membutuhkan bimbingan dari orang dewasa di lingkungan siswa. 


\section{DAFTAR PUSTAKA}

Agustin, M. , Puspita. R. ,. Nurinten D., Nafiqoh H, . (2020). Tipikal Kendala Guru PAUD dalam mengajar pada Masa Pandemi Covid 19 dan Implikasinya. Jurnal Obsesi : Jurnal Pendidikan Anak Usia Dini, Vol 5 Issue 1 2021) Page 334-345

Agustin. M. (2011) Permasalahan belajar dan inovasi pembelajaran. Bandung, Refika Aditama

Craswell, J. W. (2008). Educational Research. Planing, Coducting, and evaluating Quantitative and Qualitative Reseaarch. New jersey

Craswell. J. W. (2013). Research Design.Pendekatan Kualitatif, Kuantitatif dan mixed. Yogyakarta. Pustaka pelajar

Ramahani. , D., (2013). Efektivitas Konseling KOgnitif Perilaku dengan Teknik Restrukturisasi Kognifif untuk Mereduksi Kejenuhan Belajar Peserta Didik. Skripsi. Bandung. Universitas Pendidikan Indonesia

Syamsudin, A (2003). Psikologi Pendidikan. Bandung, Remaja Rosda Karya

Santrock. W, John. (2003). Adolescence.Perkembangan Remaja. Jakarta . Erlangga

Kuntari, D. (2020), https://www.universitaspsikologi.com/2020/04/pengertiankelelahan-emosional.html (on line) kamis pukul 21,30

Willis .S,. (2009). Konseling Keluarga (FAMILY COUNSELING). Bandung. Alfabrta

Yusuf ., S. (2010). Psikologi Perkembangan Anak dan Remaja. Bandung. Remaja Rosda Karya

Yusuf, (20201) Pentingnya Peran Orang Tua Dalam Kegiatan Belajar Online pada Anak - Minews ID. (on line) kamis pkl 21.00 